\title{
The pivotal sign of CANVAS
}

回

Figure 1 Video-oculography of impaired visually enhanced vestibulo-ocular reflex and pathologic head impulse test
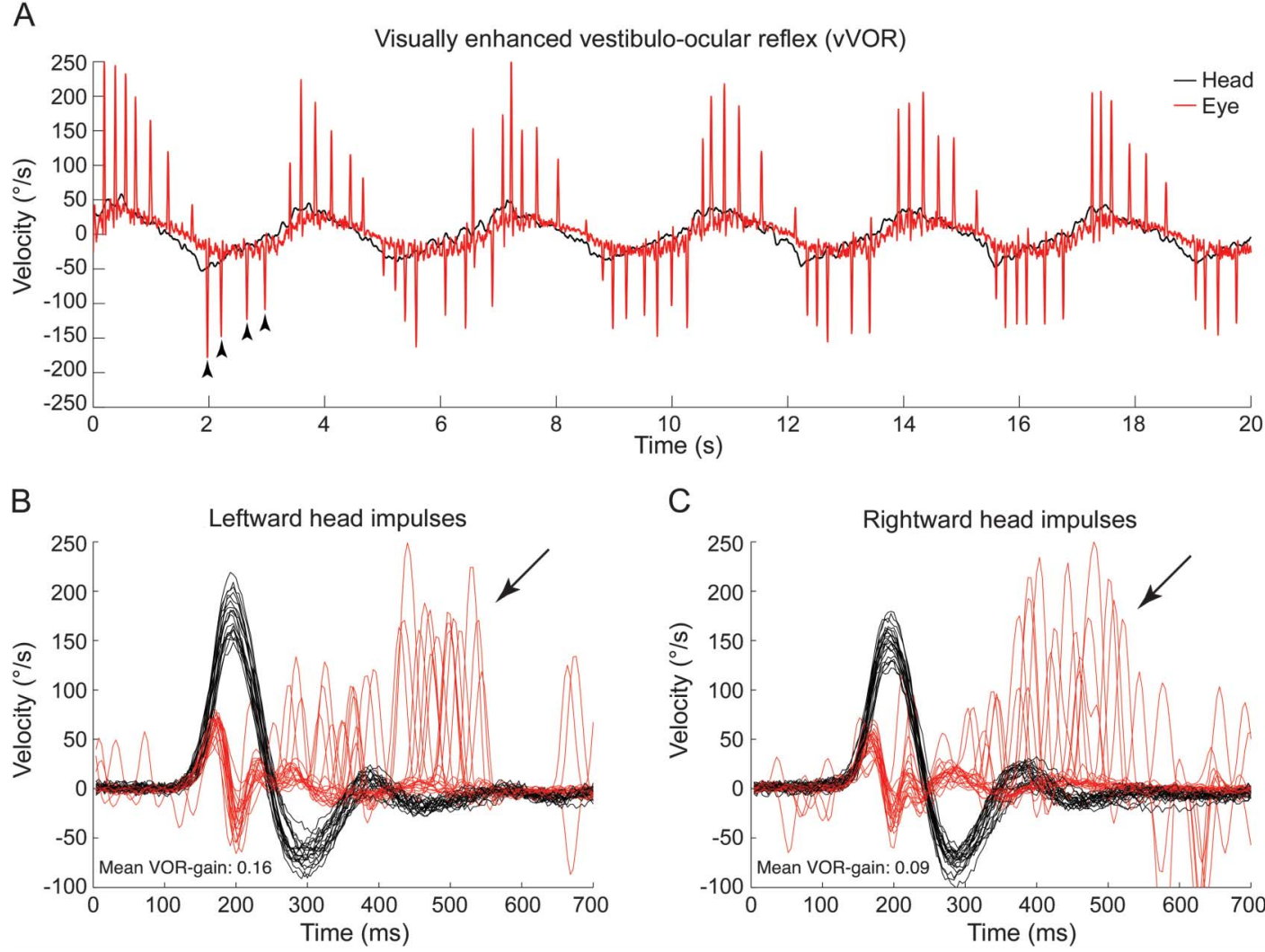

(A) Slow head rotations demonstrate an impaired visually enhanced vestibulo-ocular reflex with multiple catch-up saccades (arrowheads) instead of smooth compensatory eye movements. (B, C) The video head impulse test shows bilaterally reduced vestibulo-ocular reflex gains with overt catch-up saccades (arrows) after head rotation to either side.

Supplemental data at www.neurology.org
A 75-year-old woman complained about insecure gait since age 55. Clinical examination revealed signs of cerebellar ataxia, bilateral vestibulopathy, and peripheral sensory impairment. Sensory nerve action potentials were absent. The visually enhanced vestibulo-ocular reflex (VVOR) was impaired (video on the Neurology ${ }^{\circledR}$ Web site at www.neurology.org, figure 1) and the diagnosis of cerebellar ataxia (figure 2) with neuropathy and bilateral vestibular areflexia syndrome (CANVAS) was made. ${ }^{1}$ CANVAS is considered to be a recessive disorder with a mean age at onset of 60 years. ${ }^{2}$ VVOR impairment is its characteristic clinical sign. ${ }^{2}$ It can only be elicited if both smooth-pursuit eye movements and the vestibulo-ocular reflex are deficient. Normally, both are redundant at low head velocities. ${ }^{2}$

Jens Alexander Petersen, MD, Werner W. Wichmann, MD, Konrad Peter Weber, MD

From the Departments of Neurology (J.A.P., K.P.W.), Neuroradiology (W.W.W.), and Ophthalmology (K.P.W.), University Hospital Zurich, Switzerland.

Author contributions: J.A. Petersen recorded the video and wrote the manuscript. W. Wichmann acquired the MRI and revised the manuscript. K.P. Weber designed the study, acquired the eye movement data, and revised the manuscript.

Study funding: Supported by the Betty and David Koetser Foundation for Brain Research. 


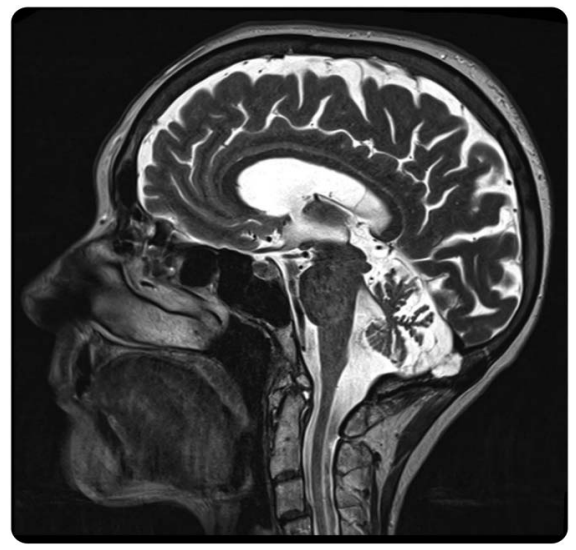

Marked cerebellar atrophy involves the vermal lobules VI, VIla, and VIlb. Note also the spinal atrophy. CANVAS = cerebellar ataxia with neuropathy and bilateral vestibular areflexia syndrome.

Disclosures: J. Petersen and W. Wichmann report no disclosures. K. Weber acts as an unpaid consultant and has received funding for travel from GN Otometrics. Go to Neurology.org for full disclosures.

Correspondence to Dr. Weber: konrad.weber@usz.ch

1. Szmulewicz DJ, Waterston JA, Halmagyi GM, et al. Sensory neuropathy as part of the cerebellar ataxia neuropathy vestibular areflexia syndrome. Neurology 2011;76:1903-1910.

2. Szmulewicz DJ, Waterston JA, MacDougall HG, et al. Cerebellar ataxia, neuropathy, vestibular areflexia syndrome (CANVAS): a review of the clinical features and video-oculographic diagnosis. Ann NY Acad Sci 2011;1233:139-147.

\section{NeuroImages Are Free at www.neurology.org!}

All Neurology ${ }^{\circledR}$ NeuroImages can now be freely accessed on the Neurology Web site. See them at www.neurology.org, where you can also sign up for journal email alerts and check out other online features, including the Resident \& Fellow section, Neurology: Clinical Practice, and the weekly Neurology Podcasts. 


\title{
Neurology
}

\author{
The pivotal sign of CANVAS \\ Jens Alexander Petersen, Werner W. Wichmann and Konrad Peter Weber \\ Neurology 2013;81;1642-1643 \\ DOI 10.1212/WNL.0b013e3182a9f435
}

This information is current as of October 28, 2013

$\begin{array}{ll}\begin{array}{l}\text { Updated Information \& } \\ \text { Services }\end{array} & \begin{array}{l}\text { including high resolution figures, can be found at: } \\ \text { http://n.neurology.org/content/81/18/1642.full }\end{array} \\ \text { Supplementary Material } & \begin{array}{l}\text { Supplementary material can be found at: } \\ \text { http://n.neurology.org/content/suppl/2013/10/26/81.18.1642.DC1 } \\ \text { This article cites } 2 \text { articles, } 1 \text { of which you can access for free at: } \\ \text { heftp://n.neurology.org/content/81/18/1642.full\#ref-list-1 }\end{array} \\ \text { Subspecialty Collections } & \begin{array}{l}\text { This article, along with others on similar topics, appears in the } \\ \text { following collection(s): } \\ \text { Gait disorders/ataxia } \\ \text { http://n.neurology.org/cgi/collection/gait_disorders_ataxia }\end{array} \\ \text { Permissions \& Licensing } & \begin{array}{l}\text { Information about reproducing this article in parts (figures,tables) or in } \\ \text { its entirety can be found online at: } \\ \text { http://www.neurology.org/about/about_the_journal\#permissions }\end{array} \\ \text { Reprints } & \begin{array}{l}\text { Information about ordering reprints can be found online: } \\ \text { http://n.neurology.org/subscribers/advertise }\end{array}\end{array}$

Neurology ${ }^{\circledR}$ is the official journal of the American Academy of Neurology. Published continuously since 1951, it is now a weekly with 48 issues per year. Copyright (C 2013 American Academy of Neurology. All rights reserved. Print ISSN: 0028-3878. Online ISSN: 1526-632X.

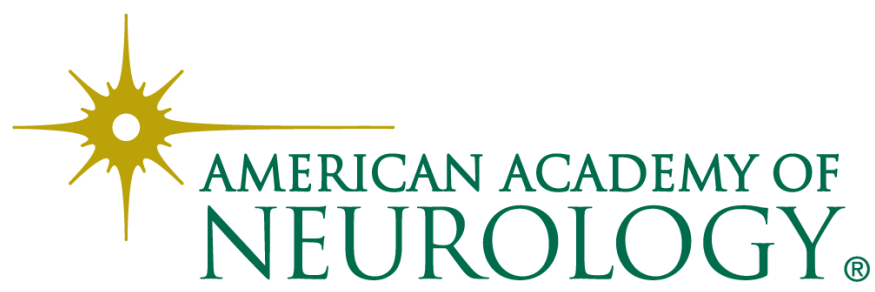

